Open Access

\title{
Market control: understanding the China's construction industry
}

Wei Zhao

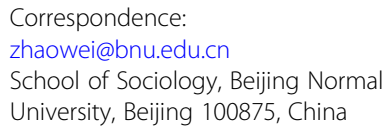

Correspondence:

zhaowei@bnu.edu.cn

School of Sociology, Beijing Normal

University, Beijing 100875, China

\begin{abstract}
Research on the labor process was initiated by the American economist Harry Braverman in the 1970s. This theory has been the main departure point for sociological research on labor issues in China. Since the beginning of the new century, research has taken new directions, such as the exploration of changes in the mode of control of workers. Based on that perspective, this article analyzes the specificities of the labor process of the Chinese building industry. It suggests to pay much more attention to social factors, such as the labor market, to understand the China's building industry.

Keywords: China, Construction industry, Labor process, Market control
\end{abstract}

\section{Research of the labor process}

\section{From production control to market control}

The concept of labor process was first mentioned by Karl Marx in Das Kapital but it was only a century later that Braverman developed the labor process theory. Once Labor and Monopoly Capital was published in 1974, its influence was universal and interdisciplinary. The theory ties together the unequal strength of work and political economics, capital expansion and the capitalist workplace. Discussion of the labor process influenced many disciplines. Research was concentrated on the aspects of management control, de-skilling and deregulation. It was also criticized for separating workplace conflict from monopolistic capitalism, large companies, the labor market and the government (Smith, 2015).

Control is the main concept of the labor process theory describing the relations between the management and the workers. Braverman connected control with Taylorism, the scientific management methods and technology progress. He argues that control is connected to low trust, coercion, extremely limited worker representation and a directly controlled work environment. Through case study, Burawoy (1979) attempted to understand how workers 'consent is won in a large, modernized, unionized and stable internal labor market, as well as the social life and labor process in a non-coercive enterprise. The concepts of "hegemonic production politics" and "factory regime" proposed in his 1985 work The Politics of Production gave rise to a new upsurge of research on the labor process.

With the building of the global production system and the development of new management methods, the research on the labor process began to focus on the impact of

(c) The Author(s). 2018 Open Access This article is distributed under the terms of the Creative Commons Attribution 4.0 International License (http://creativecommons.org/licenses/by/4.0/), which permits unrestricted use, distribution, and reproduction in any medium provided you give appropriate credit to the original author(s) and the source, provide a link to the Creative Commons license, and indicate if changes were made. 
flexible employment relations. The scope of research was extended to the newly industrialized countries, including China. New issues emerged. First, the formalization of global production chains and the widespread adoption of outsourcing and subcontracting seriously affected the management structures. It had a huge effect on work organization and human resource strategies (Robinson and Rainbird, 2013). Outsourcing and subcontracting obscured the boundaries of the organization; the traditional boundaries between managers and employees became blurred. Enterprises also adopt the labor dispatch, temporary and precarious employment model. Companies employ an increasing number of workers out of direct employment relationships. In contrast to the changes of the production model, the vertical control relationship of the bureaucracy changes. The subcontracting and outsourcing breaks down the production tasks; production units shrink; a new "family production system" emerges. At the end of the production chain, the main company changes the control style from direct management of the production process into final product quality control.

Second, the development of technology and flexible employment relationship changes the management methods, and also the control at the workplace level. Computer technology makes the global production chain possible and brings about changes in production organization. The foreman (gongtou) of the smallest production unit becomes the controller. In the workplace, simple and direct control, such as piece-rate system, rises again. The research has linked the internal control of the enterprise with the shape of the labor relationship with the market (including the labor market and the product market). Market control rather than control of the production process is concerned. It means the control is not only based on a long-term/permanent employment relationship, but also on a flexible labor market.

Third, as capitalism flows across the globe, space has become a major factor in labor control. Standardized management methods, through replication and relocation in various countries, have been modified to suit national conditions (Beynon, 2016). After the developing countries were pushed into the global capitalist system, the old form of the labor process changed (Smith, 2015). The other change is the transfer of management methods among various industries. An increasing amount of the employed population in developed countries left the manufacturing industry and shifted to professions of the services. The McDonalds production method can be regarded as an expansion of the Ford system and an extension of the lean production labor process. Today, the service industry management style, in turn, affects the manufacturing, construction and other sectors.

\section{Labor process in China}

In China, the labor process theory was first used by overseas scholars in the late 1990s, and later drove the attention of domestic scholars (Shen, 2014). Among the research, Lee (1999), Chan and Zhu (2003), Zhang (2008), Zhao (2011) and so on focused on manufacturing sectors, such as the footwear, the textile industry, the automobile industry and the home appliances industries. Research was also done on the construction and catering industries (Shen, 2007; He, 2009), trying to identify a labor process "with Chinese characteristics". These studies all show that, after entering China, the Western management model changed and adapted itself to the local context. For instance, because of the strong support for economic development within the bureaucracy, local 
governments tend to be biased towards capital forces; regardless of the types of ownership or industry, the power of capital is very strong. Furthermore, migrant workers coming from the countryside represent a large part of the workers. The role of the union and other kinds of workers organizations are also limited; therefore, labor control is very harsh at the enterprise level. In addition, Chinese cultural traditions and gender factors are also taken into account.

The above researches are mainly based on Burawoy's notion of factory regimes; they focus on the control mode at the enterprise or the sectorial level, and put forward some new concepts, such as the notion of hegemonic relations (Shen, 2007) or duality of the factory regimes (Zhang, 2008). From the perspective of the subjectivity of workers, issues such as the existence of a proletarian social class or the persistence of regional and kinship relationships among workers, have been looked at. Some studies have focused on labor markets changes. For example, a research team from Tsinghua University has conducted surveys on the short-term employment style of the new generation of migrant workers. In these studies, the production itself and the relationships within the enterprises are the main topic, whereas the labor market and other social factors are neglected.

The working condition of migrant workers in the construction industry has recently become a hot topic in labor studies. Various issues are addressed, such as the wage arrears, the low labor contracts rate, and the labor control in the context of the subcontracting system, the subjectivity of workers and their capacity to protest. The subcontracting system is highly criticized, considered as a consequence of the integration of neoliberal capital flexibility and the logics of the urban development strategies (Ren and Pan, 2010); similar to the post-Fordist system that appeared in the late 1980s, subcontracting is a flexible mode of capital accumulation (Pan and Lu, 2009). It is argued that the main reason why the rights and interests of migrant workers in the construction industry are infringed is the subcontracting system. A specific Chinese characteristic is that more than $90 \%$ of the construction workers are migrants (Shen, 2007; Cai and Jia, 2009). Swider (2015) suggests that the employment relationship in the construction industry is very complex. She divides the informal employment relationship into intermediary employment, embedded employment and individual forms. The labor market is linked to the employment relationship and takes into account the role of the government. She argues it is difficult to rely on formal labor contract to regulate employment relations, as kinship and other personal relationships and other socio-economic arrangements play an important role in a non-standardized despotic market. The above researches explore the characteristics of the labor process in China's construction industry in general. However, it over focuses on the Chinese characteristics of the subcontracting system and on the description of the structural characteristics of migrant workers; it is only concerned by the internal control process. Swider's research provides a good perspective, but she doesn't take into account the production characteristics of the construction industry itself.

The next section will explore the change of labor control from the view start of the construction industry production management model changes. This study is based on a three-year empirical study in Beijing. From 2012 to 2015, in cooperation with a labor NGO (non-governmental organization), from June to August each year, Approximately 20 construction migrant workers, managers in workplaces were interviewed per year. 
Totally 68 interviews were conducted at construction sites in Daxing and Fangshan districts of Beijing. The 68 interviewed migrant workers are male and only 5 are female. The female workers are the wives of the construction workers, and they work in the same work year. The workers average age is 40 years old, some of them are elder than 60. In Beijing, migrant workers form most important share of the construction workforce. The workers are mainly come from north provinces, such as Hebei, Henan and Shandong province, a few from Sichuan province. More them half of the workers signed the contracts, but they did not have the copies of the contracts.

In order to understand the production management and the characteristics of the workers' organization, 12 semi-structured interviews were conducted with managers, technicians and trade union officials in a large state-owned general contract company. In addition, we took part in some NGO's activities, such as migrant workers dormitory visits, legal and occupational safety training activities, in order to understand of the characteristics of labor process in China's construction industry.

\section{The production management and labor process of the construction industry}

Unlike manufacturing industry, the development of the construction industry runs through the entire pre-capitalist, industrial capitalist and post-industrial stages. Furthermore, the development and modernization of industrial capitalism in the usual sense had not had a great effect on changes in the construction industry's production management system (Thiel, 2007). At the pre-industrial stage, the construction industry was controlled by "master workers" in the building guilds. They controlled and monopolized construction techniques, and in that way controlled the recruitment, wages and working hours of people employed in construction projects. Apart from particular large-scale government or church projects, architectural design and production were not separated, and trade guilds controlled the entire building production process. After the Second World War, the demand for residential buildings increased substantially, spurring a process of industrialization in the construction industry. Industrialization of construction erase the characteristics of standardization of design, prefabrication of components and mechanization on site. The industrialization of construction directly resulted in the separation of architectural design, engineering and production (Ji, 2011).

For a long time there were vast differences between the production management methods of the construction industry and the manufacturing industry, and so-called scientific management methods were very hard to implement in the construction industry. But in recent years, whether in terms of management methods, labor process or worker composition, a trend toward uniformity has emerged between the construction and manufacturing industries. The construction industry seems to be impacted by globalization. In fact, the production management, the labor process and even the workers' structure in different countries have shown similar characteristics:

First, subcontract system became a relatively common production management system in worldwide. General company manages project, relying on labor subcontractor or "foreman" to provide labor. In the form of organization of the construction industry, it shows the characteristics of "quasi firm". "Quasi-firm" features have been extended to the workplace. Although there is direct supervision by general company, the actual operation of the basic workplace by the grassroots managers, that is, "foreman" control. The subcontractor, especially at the lowest level, is usually a skilled worker (Thiel, 
2007). The general company assigns the task to the professional and labor subcontractor through the marketization of bidding. However, in practice, many subcontractors followed the general company for long period. Besides of the market relationship, the informal trust relationship also plays an important role in the process of subcontracting. In terms of its operational methods and time of formation, the subcontracting system of the construction industry is basically indistinguishable from outsourcing and subcontracting in the globalized manufacturing chain.

Second, the labor process is realized through "market control" (Mustchin, 2014), with the characteristics of the flexibility and precarious employment relations. Burawoy (1979) himself believed that introducing centralized management authority to the construction industry would be ineffective. The labor process must occur within a bureaucratically managed workshop in order to achieve capitalism's efficiency. Applebaum (1982) analyzed the particularities of the construction industry, i.e., its local character, lack of standardization, and the periodic and uncertain nature of the work. He notes that because many factors in the production process are uncertain and unpredictable, the construction industry is unable to use bureaucratic labor control. Unlike the manufacturing industry, its management methods do not make wholesale use of the scientific management pervasively adopted in factories. It is rare to see fixed, detailed management and regulation in the construction industry. As soon as they got a project, workers have to establish new labor relations, informal standards and an informal power structure. The management of workers is done through "market control", that is, in each new project, the workers are "re-employed". And their wage has to be decided. The development of construction technology, especially after extensive use of prefabricated products, has greatly reduced the demand for the skilled workers. The majority of workers are unskilled workers. In order to control the quality of the project, the general company directly employs a small number of skilled workers, while the majority of non-skilled workers are in the form of short-term employment.

Third, migrant workers take great proportion in the construction industry. Unlike the manufacturing industry, the feature of construction industry is basically "local capital, migrant workers". In the world, the construction industry generally employs the informal, especially immigrations (Swider, 2015). For example, migrant workers take a large proportion in the EU (European Union) construction industry's workers. For the purpose of reducing labor costs, the competitive international labor subcontract is very common. In a competitive labor market, migrant workers are normally temporary employed in terms of time and demand, sometimes months or weeks (Berntsen, 2016). In addition to the direct employment of construction workers, many types of labor dispatch methods have emerged. At the construction site, the migrant workers are organized into work units based on their country or the region. Hence, the trust established by the relationship of geography and kinship is more important than the contractual relationship.

With the impacts of technological progress, change of production mode and labor force structure (extensive use of migrant workers), the particularity of labor process in construction industry is no longer significant. In view of the construction industry itself, in worldwide, subcontracting, market control and migrant workers become common. Based on these factors, it is necessary to explore the labor process of China's construction industry in a larger social and economy background. 


\section{Market control: The change of labor process in China's construction industry}

Since the 1980s, urban construction has become a pillar industry, contributing a lot to economic growth. In 2015, the construction industry represent $6.86 \%$ of gross domestic product 81141 construction enterprises employ 45.37 million workers, accounting for $5.7 \%$ of the country's employed population. Enterprises demography takes the shape of a pyramid with only a few large enterprises, a small number of large and medium-sized enterprises and many small micro-enterprises (Luban Consulting, 201). Following the expansion of the construction industry along the last thirty years, the management system have gone through great changes that have seriously impacted the workers.

\section{The push toward subcontracting}

Before 1978, the construction industry used the relative easy production methods with brick and concrete structures, combining semi-industrial and on-site prefabrication. Enterprises were state-owned. Workers were both fixed and temporary workers. The fixed workers were the major part of the construction industry (Qi, 2011). Temporary workers were recruited from rural masons, carpenters and stunners, usually for tasks.

Since the early 1980s, marketization has been strongly pushed. The government's supervisory departments directly initiated and promoted reforms of the industry's production management model; the project system and subcontracting became the sole operational production model for the construction industry throughout the country. The State Council's 1984 "Provisional regulations regarding certain problems in reforming the construction industry and capital construction management system" explicitly stated that, in principle, state-owned enterprises should not recruit permanent staff except for core technical staff. At the National Construction Work Conference held in 1987, it was further proposed that China should learn from the "Lubuge Dam project management experience" and apply the project method across the board. The 1988 Construction Law provided legal clarification for the separation of the management and labor service levels, and construction companies spun off their labor service levels. The implementation of the subcontracting system was a consequence of the reform and marketization of the state owned enterprises, and also of the demand of the construction's industrialization.

Many companies laid-off the front-line workers in a very short period. For example, a large construction company in Beijing employing 70,000 workers and staff reduced its workforce to 20,000 within 3 years. At the same time, while dozens of labor companies established cooperative relations, more than 100,000 migrant workers were employed for its projects. Flexible use of migrant workers became a source of greater profits, the number of informal labor agency companies and the work teams organizing by foremen being very common. Despite regulations by various government departments, the disorder of the construction industry labor market has not been fundamentally improved. Thus, a hybrid system of employment characterize China's construction industry: on one side market-based employment and one another side relationship-based non-market-oriented employment. It is very common that the labor company gets a project through tender procedures, then subcontracts to smaller companies or foremen. After the bidding process, the main company only controls the quality of the project. If there are quality problems or delay, the subcontractor will be not be able to succeed in 
the next bidding. Subcontractors basically use the same way to control smaller companies and foremen.

\section{Migrant construction workers under the market control}

As a labor-intensive industry, with low requirements in terms of worker's skill and education levels, and flexible employment and other characteristics, the construction industry has become the main industry absorbing rural migrant workers. According to 2015 Rural Migrant Labor Monitoring Report (NBS, 2016), among the total of 277 million rural migrant laborers, $22.1 \%$ are engaged in the construction industry, second only to the manufacturing industry. Compared with other industries, migrant construction workers are more male, elder, with a lower level of education and skills.

As a consequence of the industry's production management system, the construction workers suffer from low rate of labor contracts and wage arrears. These issues have long been of great concern for governmental departments such as the Ministry of Construction, the Ministry of Human Resource and Social Security. In recent years, the rate of labor contracts has greatly improved. But migrant workers usually do not think the labor contract has any practical significance. In our interviews over the last three years, workers were asked "Do you think labor contracts are useful?"; most answers are positive, but they could not clearly state what the meaning of the useful is. In the view of most of them, region-based relationships among workers and foremen are more reliable than labor contracts. Even when they have formal contracts, they do not clearly stipulate wages, working hours or rest periods. In so doing, managers can control the workers according to the market demands. Without contract, they can employ the workers at any time. Meanwhile, they can also evaluate the workers abilities and decide whether to employ them or not in the next project. The workers are in completely passive position.

Undeniably, the problem of wage arrears is serious. Malicious arrears and no-monthly salaries should be distinguished. Settling wages on a project basis is very common on construction work yards. While the project is in progress, the foreman pays the workers living allowances on a monthly basis. The full wages are paid when the project is finished or before the Lunar New Year. Quality control lacks the manufacturing industry's exhaustive management system, strict inspection of each work procedure and control of assembly line production rate; in the construction industry, quality is ensured by an inspection when the project is finished. If quality fails to meet standards and necessitates additional work or repairs, the costs is deducted from the workers' wages. Furthermore, the length of time required for the project is usually not accounted in the wages. Paying all wages when the project is completed effectively implements monitoring and labor discipline control over the entire production process. Whereas management seems loose and less stringent management, in fact, workers are strictly controlled. Although the Government has required a system of monthly wages in the construction industry, it has not been well implemented so far.

The uncertainty of the construction production process has a direct impact on the working conditions of migrant workers, such as on the working hours. Operations take place outdoors and are affected by the weather. Therefore, the piece-work is an important control method on the workplace. $80 \%$ of the workers we interviewed are paid by 
piece-work. Many workers do not know where they will be working the next day or what their specific job will be, or even when exactly they will report for work. Workers usually use vague timeframes such as "sunrise" or "when everyone else gets up" to describe what time they go to work, and "when I can't see anymore" or "at dusk" to designate when they finish the work for the day. They use the phrase "one job" to describe the working hours for one day. Each of these "jobs" last as long as ten hours, or twelve hours during the summer and $10 \mathrm{~h}$ during the winter. For construction workers, there is almost no concept of overtime and overtime payment. Although workers have a lot of dissatisfaction with overtime work, especially in high temperature operations, there are few public complaints. They worry that too many complaints will lead to not be hired in next project.

\section{The attitude of rural migrant construction workers toward poor working conditions}

Although the harsh working conditions of migrant workers have been criticized by news and research reports, the interviews show that workers do not strong feel dissatisfaction. In most cases, they tend to accept their condition. Only in the case of serious arrears, workers would collectively act. They would unite for a short time, and once they have reach their target, the unity soon disintegrates. The role of workers 'organizations is limited. The attitude and choice of migrant workers could be regarded as a response to market control.

A first explanatory factor to the adaptation of workers to poor working conditions is related to their sociographic profiles. Construction workers, who are mostly unskilled, basically come from the low-end of labor market. The survey shows that most of them are 40 years old male with an education level of junior high school or below. More than $55 \%$ of the workers are elder than 40 years old and $92 \%$ are male. Only very limited number of workers are younger than 20. A 17 years old worker told me:

This is the first job that I got after I had graduated. My uncle works in this work yard and I followed him. I don't think that I will work there for long time. Almost all the workfellow are very old. I will try to look for a job in factory.

Because of the low level of education and skills, most construction workers have never worked in the formal labor market. Although many workers have experiences in manufacturing, they have always worked in small and informal enterprises in towns. Their working environment was poor, with non-monthly payment. Therefore, the migrant construction workers have a high degree of tolerance. In addition, while most construction sites are in the big cities, migrant workers come from the countryside and are much more compliant then urban workers, the "compliance" feature is significant (Berntsen, 2016). A worker from Shandong said:

You asked me whether I am satisfied with this. I don't know how you answer. Honestly, everyone would like to get a good job with high salary. But he should have high education level. I graduated from Junior high school 20 years before. I worked in some small factories in my hometown with very bad working condition and very low wage. Compare with this, I have no complain of my job.

A second explanatory factor are the informal - regional or kinship relationships - relationships that contribute to alleviate the contradictions the workers endure. On 
construction sites, the rural migrant laborers do not enjoy the formal organizational structure of factory workshops and teams. Nearly $90 \%$ of migrant workers we interviewed got the job through the introduction of a fellow villager or were recruited by a labor contractor. At one construction site, the workers in a contracting team engaged in waterproofing work not only all came from the same village as the contractor, but could even be considered his relatives to varying degrees. Since 2014, an increasing number of female workers work on construction sites. Because of the free dormitories, the wives of the construction workers work with their husbands. The "couple work team" fit the piece-work system and the flexible work time. A female worker said,

My husband has worked in construction site for many years. I had to stay in hometown for looking after children. Now the children grew up and I could come to Beijing to live with him. At the beginning, I help him to do some simple work. Later, we found we could well match. No need any discussion, we could decide the working and rest time by ourselves. We would like to work longer time in order to earn more money.

Some studies have found that informal relations in workplace expose the worker to greater market risks. When the labor contractor experiences a funding shortfall, in order to avoid the possibility of intense conflict, he chooses to give the "fringe workers" priority in paying the limited wages; and in order to reduce the resulting uncertainty of "core workers" running off, the labor contractor will use personal relationships to engender identification and loyalty (Cai and Jia, 2009). It is also believed that joining a construction project through an acquaintance makes migrant construction workers accept the possibility of being owed wages even before they enter the worksite (Qi, 2011).

Thirdly, the market control might shift the labor conflict outside the enterprise. Once there is a contradiction, the power outside the enterprise is needed. In the construction industry, due to the structural problems of traditional workers organizations and the lack of government regulation of the informal labor market, workers have to individually face the abuse of power by employers (Nichols, 1997). When serious conflicts occur, for example concerning work injury compensation or collective wage arrears, the government intervention is necessary. From the end of the 1990s to the present, at the end of each year, many government departments have published documents, have been involved in centralized remediation, or have set up joint offices to deal with the arrears. While the workers do not negotiate with the subcontractors or the managers of the workplace, they will go directly to the government to ask for a solution.

Fourthly, market control reduces the possibility of solidary among workers. One of the foundations of workers' solidarity is the sharing of common interests. Although improving the harsh working environment and raising wages are common demands, the flexible employment relationship determined by the labor market, the uncertainty of the labor process and the piece-rate wage system also are among the grievances of the workers. Individualized workers are not easily to be united. Only when serious wage arises occur, workers may have short-term collective action. In addition, characterized by low education and skills, strong regional ties and a high level of mobility, migrant construction workers are very hard to organize; the top-down organization form of China's labor unions makes it difficult for the organization rate of labor unions to 
effectively increase; the limited number of labor NGO, restricted by policies and funding, have little influence as well.

\section{Conclusion}

Against the backdrop of globalization, the labor processes in different industries and professions tend to homogenize. Flexibility in employment, management delegated to a lower level and uncertainty in the production process are becoming common features. The deskilling of workers is even more obvious in China as the working class is made of rural migrants. The Chinese construction industry, that was previously rather unique, share these characteristics. What analytical framework should be used to explore these issues must await new theoretical developments. Based on the concept of market control derived from the theory of labor process, we find that it is necessary to extend the research perspective beyond the production process, taking into account the labor market, immigration and other factors. This extended perspective will help to deal with labor issues from multiple perspectives.

Although the construction sector shared the similar characters in production process around the world, due to the subcontract system is very popular. In China, the implement of subcontract system is not only the result of the marketization and the change of production process, but also the push of the government. With the fast change of the employment and management methods, as well as the workers' structure, market control, instead of the traditional control inside workplace, became the main form of control. The informal and de-regulate bidding process and labor market strengthen the role of the market control.

As mentioned above, the subcontract system and the other related features of the Chinese construction sector result in the characters of the employment relations. "Informal" labour relations and bad working conditions (including wage arrears, long working time and the shortage of the safety protection) are very common. The intervene of government and the official union have played limited in improving the working condition. It is necessary to pay attention on the role of market, both of labour market and the marketization of construction sector.

Abbreviations

EU: European Union; NGO: Non governmental organization

Acknowledgements

Only Tong Xin contributed towards the original article in Chinese. The text was translated into English by Stacy Mosher.

Funding

Does not apply.

Availability of data and materials

Original data are interviews that the author will not disclose to the public.

Author's contributions

This article is the sole work of Prof. ZHAO Wei. The author read and approved the final manuscript.

Competing interests

There are no competing interests concerning this research and its publication. 
Received: 8 May 2018 Accepted: 28 October 2018

Published online: 12 November 2018

\section{Rereferences}

Applebaum, Herbert A. 1982. Construction Management: Traditional Versus Bureaucratic Methods. Anthological Quarterly 55 (4): 224-234.

Berntsen, Lisa. 2016. Reworking labour practices: on the agency of unorganized mobile migrant construction workers. Work, employment and society 30 (3): 472-488

Beynon, Huw. 2016. Beyond Fordism. In The Sage Handbook of the Sociology of Work and Employment, ed. S. Edgell, H. Gottfried, and E. Granter, 306-328. London: Sage.

Burawoy, Michael. 1979. Manufacturing Consent: Changes in the Labor Process Under Monopoly Capitalism. Chicago: University of Chicago Press.

Cai, He, and Wenjuan Jia. 2009. Lu qiao jiansheye zhong bao gongtou gongzi fafang de 'chaxu ge ju. Chinese Journal of Sociology 5 .

Chan, Anita, and Xiaoyang Zhu. 2003. Disciplinary Labour Regimes in Chinese Factories. Critical Asian Studies 35 (4): $559-584$

He Mingjie, 2009, "Laodong yu jiemei fenhua", Sociological Studies, No.2.

Ji, Yingbo. 2011. Jianzhu gongyehua fazhan yanjiu. Beijing: Chinese Construction Industry Press.

Lee, Ching Kwann. 1999. From Organized Dependence to Disorganized Despotism: Changing Labour Regimes in Chinese Factories. The China Quarterly 157: 44-71.

Mustchin, Stephen. 2014. Union modernisation, coalitions and vulnerable work in the construction sector in Britain. Industrial Relations Journal 45 (2): 121-136.

Nichols, Theo. 1997. The Sociology of Industrial Injury. London: Mansell.

Pan, Yi, and Huilin Lu. 2009. Shei geng xuyao bao gongtou. Nanfeng Chuang 9: 52-55.

Qi, Xin. 2011. Qianxin yu taoxin. Beijing: Capital University of Economics and Business Press.

Ren Yan and Pun Ngai, 2010 "Jianzhuye baogong zhi: nongcun laodong lishi yongyu chengshi kongjian shengchan de zhidu luoji", Open time, No.5.

Robinson, Pamela K., and Helen Rainbird. 2013. International Supply Chains and the Labour Process. Competition and Change 17 (1): 91-107.

Shen, Yuan. 2007. Shichang, jieji yu shehui. Beijing: Social Science Documents Press.

Shen Yuan, 2014, "Zhuanxing shehuixue shi ye xia de laogong yanjiu", Chinese Workers, No.5.

Smith, Chris. 2015. Continuity and Change in Labor Process Analysis Forty Years After Labor and Monopoly Capital. Labor Studies Journal 40 (3): 222-242.

Swider, Sarah. 2015. Building China: precarious employment among migrant construction workers. Work, Employment and Society 29 (1): 41-59.

Thiel, Darren. 2007. Class in Construction: London Building Workers, Dirty Work and Physical Cultures. The British Journal of Sociology 58 (2): 227-251.

Zhang Lu, 2008, "Lean Production and Labour Control in the Chinese Automobile Industrial in a Age of Globalization", International Labour and working Class History, 73 (1): 24-44.

Zhao, Wei. 2011. Gongchang zhidu chongjian zhong de gongren. Beijing: Social Science Documents Press.

\section{Submit your manuscript to a SpringerOpen ${ }^{\circ}$ journal and benefit from:}

- Convenient online submission

- Rigorous peer review

- Open access: articles freely available online

High visibility within the field

- Retaining the copyright to your article

Submit your next manuscript at $\boldsymbol{s p r i n g e r o p e n . c o m ~}$ 